\title{
Original
}

\section{Investigation of Cell Migration and Invasion Using Real-time Cell Analysis, as well as the Association with Matrix Metalloproteinase-9 in Oral Squamous Cell Carcinomas}

\author{
Tomohiro OnO ${ }^{1)}$, Shinichi IwaI ${ }^{1,2)}$, Shunya EgawA ${ }^{1)}$, \\ Takehiko SAmbe ${ }^{1)}$, Takatoshi ToKudome ${ }^{1)}$, Kenichiro Kawaguchi ${ }^{1)}$, \\ Takeshi Hayashi ${ }^{1)}$ and Katsuji OguCHI ${ }^{1)}$
}

\begin{abstract}
The recently developed technology of real-time cell analysis (RTCA) was designed to analyze cell migration and invasion in vitro. In this study, we investigated these cellular factors in oral squamous cell carcinomas (OSCCs) of the tongue and floor of the mouth with RTCA. We also examined the associated matrix metalloproteinases (MMPs) and integrins. We used the cell lines SCC-4 and SAS, which are human poorly differentiated OSCCs from the tongue, and HO1-u-1, which are human poorly differentiated OSCCs from the floor of the mouth. Using RTCA, cell migration was assessed on fibronectin-coated CIM-Plates, and invasion was assessed on fibronectin- and matrigel-coated CIM-Plates. SCC-4 cells demonstrated a high ability for cell migration and invasion compared with SAS and HO-1-u-1 cells. The SCC-4 cells also expressed high levels of MMP-9 and integrin $\alpha 1$ mRNA compared with SAS and HO-1-u-1 cells. The MMP inhibitor Marimastat blocked migration and invasion of all OSCCs. The findings suggest that MMP9 is associated with cell migration and invasion in OSCCs, and indicate that RTCA will be useful for analyzing the metastatic capability of OSCCs and developing more effective new drugs for this disease.
\end{abstract}

Key words : oral squamous cell carcinoma, migration, invasion, matrix metalloproteinase, real-time cell analyzer

\section{Introduction}

Oral squamous cell carcinoma (OSCC) is a well-known malignancy that accounts for more than $90 \%$ of all oral cancers and has a high incidence of cervical micrometastases ${ }^{1,2)}$. The presence of lymph node metastases is one of the most important and widely accepted prognostic factors related to the survival of patients with OSCC $^{2)}$.

The metastatic cascade is a complex, multistage process involving modulation of cell phenotype, cell migration, and dynamic homeotypic and heterotypic cell-cell interactions ${ }^{3)}$. Moreover,

\footnotetext{
${ }^{1)}$ Department of Pharmacology, Showa University School of Medicine, 1-5-8 Hatanodai, Shinagawa-ku, Tokyo 142-8555, Japan.

2) Department of Healthcare and Regulatory Sciences, Showa University School of Pharmacy.
} 
increased tumor size and microvascular invasion are the most important, independent prognostic factors for predicting survival in patients with $\mathrm{OSCC}^{4)}$.

Matrix metalloproteinases (MMPs) are a family of zinc-dependent proteases involved in cancer proliferation and metastasis due to their roles in extracellular matrix (ECM) degradation, cellular migration, tissue remodeling, and angiogenesis ${ }^{5)}$. Activated MMPs degrade many ECM and basement membrane components ${ }^{6,7)}$, and as tumor cells secrete MMPs to degrade the interstitial matrix, microtracks of weakened and digested matrix result, enabling tumor cell migration ${ }^{8)}$. In particular, MMP-2 and MMP-9 are highly expressed in OSCC compared with normal oral mucosa tissues, with tumor progression producing further increases at the mRNA and protein levels ${ }^{9,10)}$. In addition, MMP-2 and MMP-9 are closely associated with tumor invasion and metastasis in a variety of human tumors ${ }^{11-13)}$.

Integrins are transmembrane heterodimeric receptors that interact with the ECM. By associating laterally on the cell membrane with other proteins and by signaling to modify the expression of molecules such as matrix-modifying proteolytic enzymes, integrins coordinate the interaction of a cell with the $\mathrm{ECM}^{14)}$. Expression of integrins and proteases of the MMP and plasminogen activator families is altered in both healing and malignant epithelium, implicating these molecules as key factors in the process of re-epithelialization, cell migration, and tumor invasion $^{14,15)}$.

Many different experimental methods have been developed to assay tumor cell migration and invasion in vitro ${ }^{16)}$, with real-time monitoring a major technical challenge. The recently developed xCELLigence real-time cell analysis (RTCA; Roche Applied Science, Mannheim, Germany) system has emerged as an alternative non-invasive and label-free approach that uses impedance detection for the continuous monitoring of cellular proliferation, migration, and invasion in real time on a cell culture level ${ }^{17,18)}$. In this study, we applied RTCA to OSCCs of the tongue and floor of the mouth, and examined the associated MMPs and integrins.

\section{Materials and Methods}

\section{Cell lines and reagents}

SCC-4 (JCRB9118) ${ }^{19)}$ and SAS (JCRB0260) ${ }^{20)}$ cells were established from a poorly differentiated OSCC in the tongue. HO-1-u-1 (JCRB0828) cells were established from a poorly differentiated OSCC in the floor of the mouth ${ }^{21)}$. All cell lines were provided by the Health Science Research Resources Bank (Osaka, Japan). Marimastat, a broad-spectrum MMP inhibitor, was obtained from Wako Pure Chemical Industries, Ltd. (Osaka, Japan).

\section{Cell culture}

SAS and HO-1-u-1 cells were cultured at $37^{\circ} \mathrm{C}$ in humidified $5 \% \quad \mathrm{CO}_{2}$ and $95 \%$ air in $45 \%$ Dulbecco's modified Eagle's medium, 45\% Ham's F12 medium (DMEM/F12), 10\% fetal bovine serum (FBS), $100 \mathrm{U} / \mathrm{ml}$ penicillin, and $100 \mu \mathrm{g} / \mathrm{ml}$ streptomycin. The medium was changed every 3days. SCC-4 cells are considered undifferentiated cancer cells and were cultured in the same conditions in DMEM/F12 with $0.4 \mu \mathrm{g} / \mathrm{ml}$ hydrocortisone, 10\% FBS, $100 \mathrm{U} / \mathrm{ml}$ penicillin, and 
$100 \mu \mathrm{g} / \mathrm{ml}$ streptomycin. The medium was changed every 3 days.

\section{RTCA}

We used RTCA to study migration and invasion of OSCCs ${ }^{22)}$. Migration was analyzed in a CIM-Plate 16 (Roche) coated with fibronectin $(20 \mathrm{mg} / \mathrm{ml})$, while invasion was assessed using a CIM-plate 16 coated with Matrigel (1:80) (BD Biosciences, Erembodegem, Belgium) and fibronectin $(20 \mathrm{mg} / \mathrm{ml})$. For each analysis, SCC-4 cells $\left(1.6 \times 10^{5}\right)$, SAS cells $\left(3.2 \times 10^{5}\right)$, or HO-1-u-1 cells $\left(3.2 \times 10^{5}\right)$ were seeded in the upper chamber of a CIM-Plate 16 in $100 \mu 1$ medium for each cell line without FBS and with or without Marimastat (10 or $100 \mu \mathrm{M})$. The upper chamber was then placed on the lower chamber of the CIM-Plate 16, which contained growth medium supplemented with $10 \%$ FBS as an attractant.

\section{$R N A$ isolation and quantitative real-time RT-PCR (Q-PCR)}

Q-PCR was used to quantify the mRNA levels of MMP-2 and 9 and integrin $\alpha 1$ and $\beta 1$ in OSCCs. Total RNAs were extracted with NucleoSpin RNAII (MACHEREY-NAGEL GmbH \& Co. KG, Duren, Germany), and reverse transcription of total RNA was performed using PrimeScript RT Master Mix from TaKaRa Bio Inc. (Shiga, Japan). The cDNAs were amplified using primers designed by ProbeFiber software (Roche). Table 1 details the primers used, the Roche Universal ProbeLibrary Probe numbers, and accession numbers. Amplification was performed with a LightCycler (Roche) using LightCycler TaqMan Master mix (Roche). The PCR reaction parameters were as follows: $95^{\circ} \mathrm{C}$ for $10 \mathrm{~min}, 45$ cycles (except 18s, which was performed for 25 cycles) of $95^{\circ} \mathrm{C}$ for $10 \mathrm{~s}, 60^{\circ} \mathrm{C}$ for $30 \mathrm{~s}$, and $72^{\circ} \mathrm{C}$ for $1 \mathrm{~s}$. Fluorescence data were analyzed with LightCycler software (Roche). The mRNA levels were compared to 18s rRNA as a standard, and relative expression ratios were calculated ${ }^{23)}$.

Table 1. Nucleotide sequences of the primers used for PCR

\begin{tabular}{|c|c|c|c|c|}
\hline Gene & & Sequence & Accession number & Probe number \\
\hline MMP-2 & $\begin{array}{l}\text { Sense primer } \\
\text { Antisense primer }\end{array}$ & $\begin{array}{l}\text { 5'-gagggggcaggtcatgtag-3' } \\
\text { 5'-ggctggatgagatcttgctg-3' }\end{array}$ & AY738117.1 & $\# 58$ \\
\hline MMP-9 & $\begin{array}{l}\text { Sense primer } \\
\text { Antisense primer }\end{array}$ & $\begin{array}{l}\text { 5'-gaaccaatctcaccgacagg-3' } \\
\text { 5'-gccacccgagtgtaaccata-3' }\end{array}$ & NM_004994.2 & \#6 \\
\hline Integrin $\alpha 1$ & $\begin{array}{l}\text { Sense primer } \\
\text { Antisense primer }\end{array}$ & $\begin{array}{l}\text { 5'-aattggctctagtcaccattgtt-3' } \\
\text { 5'-caaatgaagctgctgactggt-3' }\end{array}$ & NM_181501.1 & $\# 14$ \\
\hline Integrin $\beta 1$ & $\begin{array}{l}\text { Sense primer } \\
\text { Antisense primer }\end{array}$ & $\begin{array}{l}\text { 5'-cgatgccatcatgcaagt-3' } \\
\text { 5'-acaccagcagccgtgtaac-3' }\end{array}$ & NM_002211.3 & $\# 65$ \\
\hline $18 \mathrm{~s}$ & $\begin{array}{l}\text { Sense primer } \\
\text { Antisense primer }\end{array}$ & $\begin{array}{l}\text { 5'-gcaattattccccatgaacg-3' } \\
\text { 5'-gggacttaatcaacgcaagc-3' }\end{array}$ & X03205.1 & \#48 \\
\hline
\end{tabular}



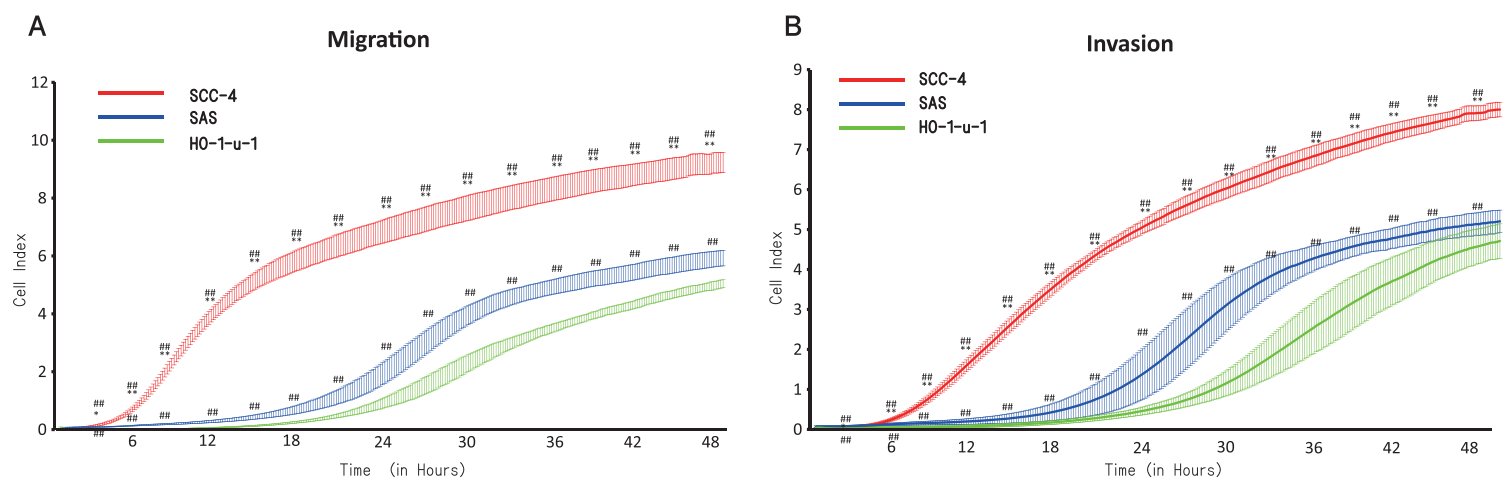

Fig. 1. This graph shows migration (A) and invasion (B) in SCC-4, SAS, and HO-1-u-1 cell lines as indicated by the color code. Cells were resuspended in their respective growth media and seeded into the wells of a CIM-Plate 16 (SCC-4; $1.6 \times 10^{5} /$ well, SAS and HO-1-u- ; $3.2 \times 10^{5} /$ well) of the RTCA instrument. Changes in impedance resulting from cells that had migrated to the bottom side of the membranes were recorded every 15 min and monitored for a total of 48 hours. Data are the mean values \pm SD of eight (SCC-4 and SAS), four (A; HO-1-u-1), and three (B ; HO-1-u-1) wells. ${ }^{*} ; P<0.05$ vs. SAS cells, ${ }^{* *} ; P<0.01$ vs. SAS cells, \#\#; $P<0.01$ vs. HO-1-u-1 cells.

\section{Statistical analysis}

Data were analyzed with the Bonferroni test following one-way analysis of variance (ANOVA). All data were expressed as the mean \pm standard error (SE) or standard deviation (SD). $P$ values of less than 0.05 were considered significant.

\section{Results}

The migratory response of OSCCs was observed with RTCA on a cell culture level (Fig. 1A). This response was increased early during the culture period of SCC-4 cells (approximately 12 hours), and we observed a high cell index level compared with SAS and HO-1-u-1 cells. SAS cells showed a higher migratory response than HO-1-u-1 cells. The invasion response was slightly weaker and later compared with the migratory response in OSCCs by RTCA (Fig. 1B). The order of the migratory and invasion abilities was clearly observed with RTCA as SCC-4 $>$ SAS $>$ HO-1-u-1.

Figures 2 and 3 show the expression profiles of integrin and MMP mRNA, respectively. The level of each mRNA in HO-1-u-1 cells was set at 100\%. Integrin $\alpha 1$ mRNA levels in SCC-4 cells were 15.8 times $(P<0.01)$ higher than levels in HO-1-u-1 cells (Fig. 2A), whereas integrin $\beta 1$ (Fig. 2B) and MMP-2 (Fig. 3A) mRNA levels were not significantly different among SCC-4, SAS, and HO-1-u-1 cells. MMP-9 mRNA levels in SCC-4 cells were 4.91 times $(P<0.01)$ and 1.90 times $(P<0.05)$ higher than levels in HO-1-u-1 and SAS cells, respectively (Fig. 3B).

No cell death or morphological changes were seen in OSCCs treated with $100 \mu \mathrm{M}$ Marimastat, an MMP inhibitor. Lombard et al. ${ }^{24)}$ also reported that human colon adenocarcinoma treated with $100 \mu \mathrm{M}$ Marimastat inhibited shedding of tumor necrosis factor-alpha receptors. Therefore, there is little toxicity to OSCCs at concentrations less than $100 \mu \mathrm{M}$ Marimastat (data not shown). Figures 4 and 5 show that Marimastat added to the upper chamber at a concentration 

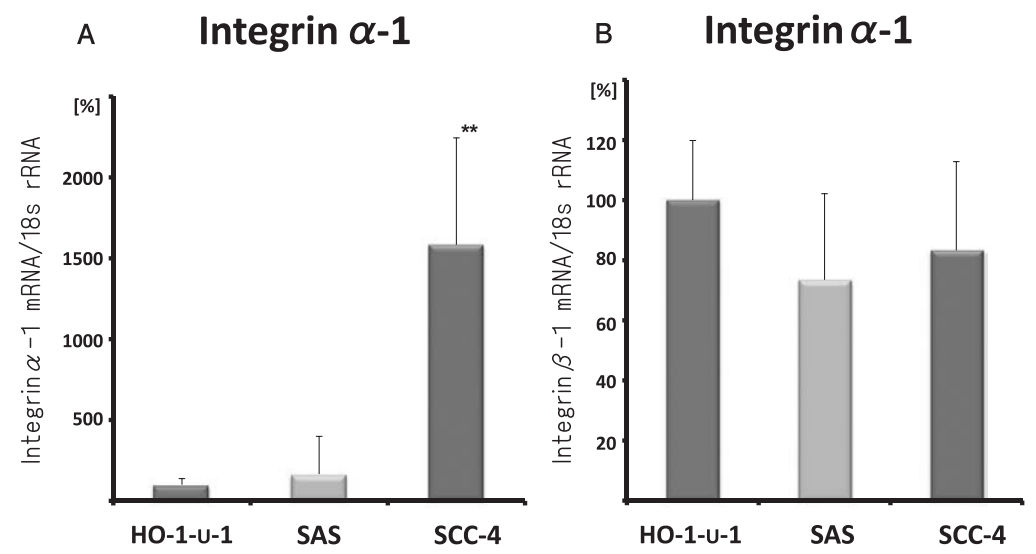

Fig. 2. (A) Integrin $\alpha 1$ and (B) Integrin $\beta 1$ mRNA expression in HO-1-u-1, SAS, and SCC-4 cells relative to HO-1-u-1 cells as determined by quantitative real-time polymerase chain reaction are shown. Data are the mean \pm SEM. ${ }^{* *} ; P<0.01$ vs. HO-1-u-1 cells.
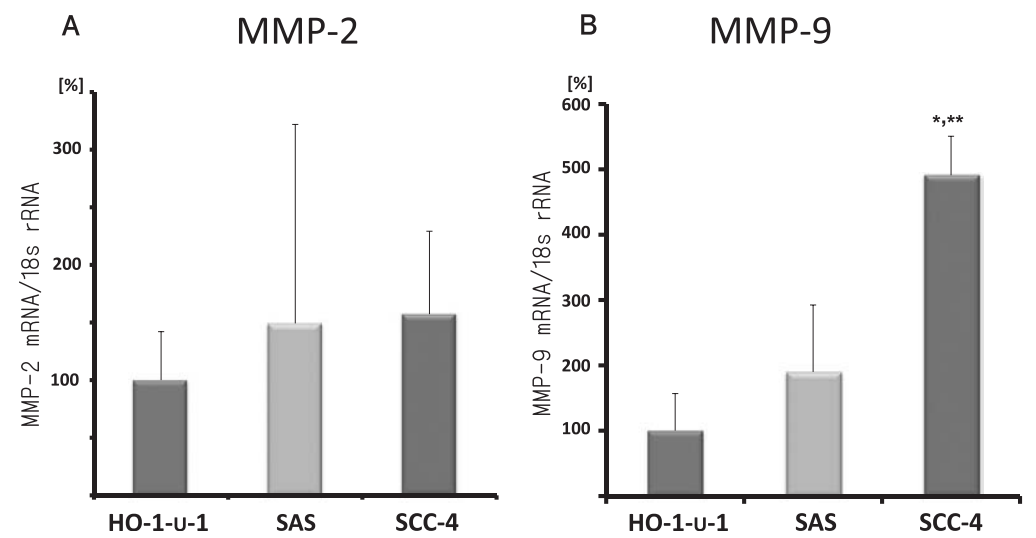

Fig. 3. (A) MMP-2 and (B) MMP-9 mRNA expression in HO-1-u-1, SAS, and SCC-4 cells relative to HO-1-u-1 cells as determined by quantitative real-time polymerase chain reaction are shown. Data are the mean \pm SEM. * $; P<0.05$ vs. SAS cells, ${ }^{* *} ; P<0.01$ vs. HO-1-u-1 cells.

of 10 or $100 \mu \mathrm{M}$ significantly inhibited the migratory and invasion responses of OSCCs in a dose-dependent manner. The migratory response of HO-1-u-1 cells at 48 hours in the presence of $100 \mu \mathrm{M}$ Marimastat was decreased by $86 \% \quad(P<0.01$; compared with control and $10 \mu \mathrm{M}$ Marimastat), while in the presence of $10 \mu \mathrm{M}$ Marimastat, migration was reduced by $49 \% \quad(P<$ 0.05 ; compared with control) after 34 hours (Fig. 4A). The migratory response of SAS cells in the presence of $100 \mu \mathrm{M}$ Marimastat was decreased by $29 \%$ after 48 hours $(P<0.01$; compared with control and $10 \mu \mathrm{M}$ Marimastat), and by $14 \%$ in the presence of $10 \mu \mathrm{M}$ Marimastat $(P<$ 0.01 ; compared with control) (Fig. 4B). The migratory response of SCC-4 cells was decreased by $44 \%$ in the presence of $100 \mu \mathrm{M}$ Marimastat after 48 hours $(P<0.01$; compared with control and $10 \mu \mathrm{M}$ Marimastat), and by $19 \%$ in the presence of $10 \mu \mathrm{M}$ Marimastat $(P<0.01$; compared with control) (Fig. 4C). The invasion response of HO-1-u-1 cells in the presence of $100 \mu \mathrm{M}$ Marimastat was decreased by $71 \% \quad(P<0.01$; compared with control and $10 \mu \mathrm{M}$ 
Marimastat) after 48 hours, while invasion in the presence of $10 \mu \mathrm{M}$ Marimastat was reduced by $86 \%(P<0.05$; compared with control) after 24 hours (Fig. 5A). The invasion response of SAS cells was decreased by $92 \%$ in the presence of $100 \mu \mathrm{M}$ Marimastat $(P<0.01$; compared with control and $10 \mu \mathrm{M}$ Marimastat) after 48 hours, and by $36 \%$ in the presence of $10 \mu \mathrm{M}$ Marimastat $(P<0.01$; compared with control) after the same time period (Fig. 5B). For SCC4 cells, the invasion response was decreased by $75 \%$ in the presence of $100 \mu \mathrm{M}$ Marimastat $(P$ $<0.01$; compared with control and $10 \mu \mathrm{M}$ Marimastat), and by $24 \%$ in the presence of $10 \mu \mathrm{M}$ Marimastat $(P<0.01$; compared with control) after 48 hours (Fig. 5C). The invasion response of HO-1-u-1 cells was similar to the migratory response. Thus, Marimastat more markedly decreased the invasion responses of SAS and SCC-4 cells compared with the migratory responses.

\section{Discussion}

In this study, we demonstrated the migratory and invasion responses associated with MMP9 in poorly differentiated OSCCs by RTCA. Prevention of cancer migration and invasion is an important strategy for improving a patient's prognosis. Cancer cell-matrix interaction is a critical step in promoting cell migration ${ }^{25,26)}$, and proteolytic degradation of the ECM is a critical event during tumor invasion and metastasis. Cell migration across ECM tissue boundaries is required in many important biological processes and is dependent on the activities of proteases such as MMPs ${ }^{27,28)}$. MMP-2 and MMP-9 are involved in metastasis ${ }^{29)}$, making MMPs target enzymes for blocking migration and invasion. Our results demonstrated that SCC-4 cells, which strongly express MMP-9, have high migration and invasion abilities. This is consistent with a report by Lu et al. ${ }^{30)}$ that showed that downregulating MMP-9 production inhibited SCC-4 cell invasion and metastasis.

We further confirmed the association of MMPs with the invasion and metastasis abilities of OSSCs using Marimastat, a broad-spectrum MMP inhibitor with pharmacokinetic properties appropriate for chronic oral administration. Marimastat shows potent inhibition of most of the major MMPs, with IC50s against MMP-2 and MMP-9 of 6 and $3 \mathrm{nM}$, respectively ${ }^{31}$. Indeed, Peterson et al. ${ }^{32)}$ showed reduced MMP-2 and MMP-9 activities in fibrosarcoma-derived HT-1080 cells by Marimastat. Marimastat was shown to inhibit tumor growth in a murine model of head and neck squamous cell carcinoma in combination with chemoradiation ${ }^{33)}$. However, clinical trials involving Marimastat have been disappointing as many patients failed to benefit from the drug and also experienced significant side effects, such as musculoskeletal toxicity ${ }^{34)}$. In this study, Marimastat was effective in blocking invasion, but not as effective in blocking migration in SCC-4 and SAS cells. Moreover, the effect required a high concentration of Marimastat $(100 \mu \mathrm{M})$.

Many cell types constitutively express MMP-2, and its promoter does not contain a TATA box, as is the case for many housekeeping genes ${ }^{35)}$. Our results showed that MMP-2 mRNA expression was not significantly different among the OSCC cell lines studied. On the other hand, MMP-9 gene transcription is inducible in most cell types ${ }^{35)}$, and can be induced in specific cell types by multiple polypeptide factors, including epidermal growth factor, plateletderived growth factor, hepatocyte growth factor/scatter factor, basic fibroblast growth factor, 

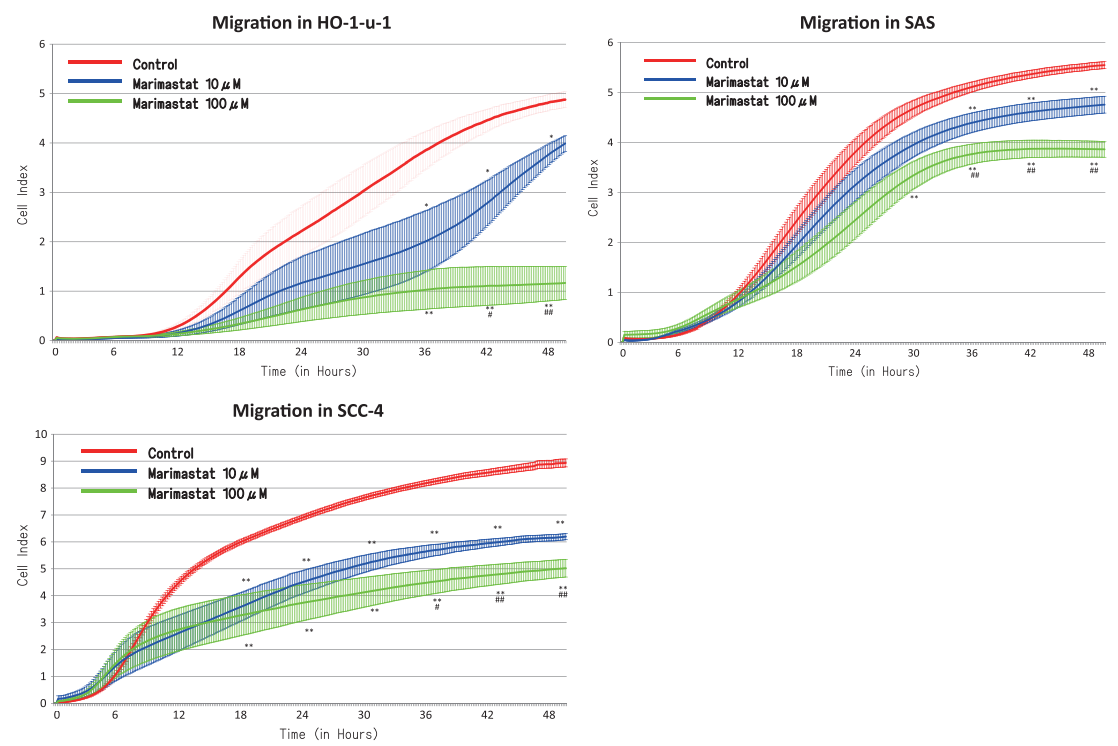

Fig. 4. This graph shows the migration of HO-1-u-1 (A), SAS (B), and SCC-4 (C) cell lines. Cells were resuspended in their respective growth media and seeded into the wells of a CIM-Plate 16 (SCC-4; $1.6 \times 10^{5} /$ well, SAS and HO-1-u- $;$; $3.2 \times 10^{5} /$ well $)$ of the RTCA instrument. Cells were allowed to migrate in the presence $(10 \mu \mathrm{M}$ or $100 \mu$ $\mathrm{M}$, added to the upper compartment of each well) or absence of Marimastat (Marimastat (-)) as indicated by the color code. Changes in impedance resulting from cells that had migrated to the bottom side of the membranes were recorded every $15 \mathrm{~min}$ and monitored for a total of 48 hours. Data are the mean values $\pm \mathrm{SD}$ of wells (A ; Control, $\mathrm{n}=6 ; 10 \mu \mathrm{M}, \mathrm{n}=6 ; 100 \mu \mathrm{M}, \mathrm{n}=4, \mathrm{~B} ;$ Control, $\mathrm{n}=18 ; 10 \mu \mathrm{M}, \mathrm{n}=18 ; 100 \mu \mathrm{M}, \mathrm{n}=7, \mathrm{C} ;$ Control, $\mathrm{n}=12$; $10 \mu \mathrm{M}, \mathrm{n}=9 ; 100 \mu \mathrm{M}, \mathrm{n}=6) .{ }^{*} ; P<0.05$ vs. control, ${ }^{* *} ; P<0.01$ vs. control, \# $P<0.05$ vs. $10 \mu \mathrm{M}$ Marimastat, \#\# $P<0.01$ vs. $10 \mu \mathrm{M}$ Marimastat.
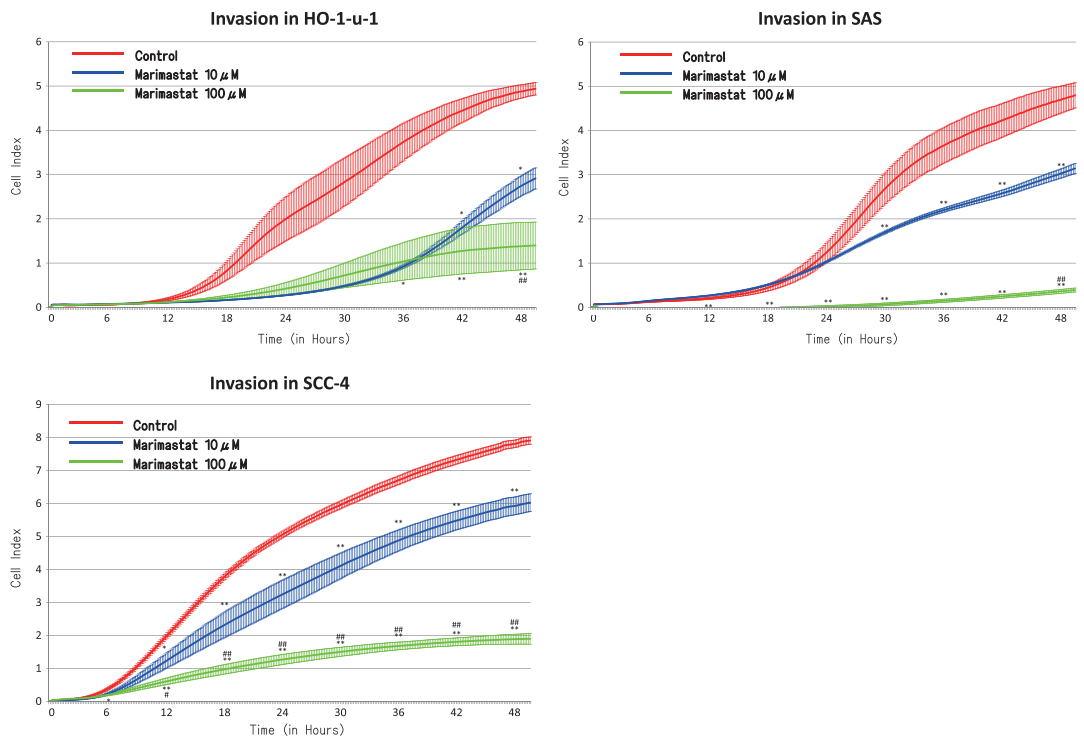

Fig. 5. This graph shows invasion of HO-1-u-1 (A), SAS (B), and SCC-4 (C) cell lines. Cells were resuspended in their respective growth media and seeded into the wells of a CIM-Plate 16 (SCC-4; $1.6 \times 10^{5} /$ well, SAS and HO-1-u- $; 3.2 \times 10^{5} /$ well $)$ of the RTCA instrument. Cells were allowed to migrate in the presence $(10 \mu \mathrm{M}$ or $100 \mu \mathrm{M}$, added to the upper compartment of each well) or absence of Marimastat (Marimastat (-)) as indicated by the color code. Changes in impedance resulting from cells that had migrated to the bottom side of the membranes were recorded every $15 \mathrm{~min}$ and monitored for a total of 48 hours. Data are the mean values \pm SD of wells (A ; Control, $\mathrm{n}=7 ; 10 \mu \mathrm{M}, \mathrm{n}=4 ; 100 \mu \mathrm{M}, \mathrm{n}=4, \mathrm{~B}$; Control, $\mathrm{n}=10 ; 10 \mu \mathrm{M}, \mathrm{n}=5$; $100 \mu \mathrm{M}, \mathrm{n}=10, \mathrm{C}$; Control, $\mathrm{n}=10,10 \mu \mathrm{M}, \mathrm{n}=10 ; 100 \mu \mathrm{M}, \mathrm{n}=10)$. $^{*} ; P<0.05$ vs. control, ${ }^{* *} ; P<0.01$ vs. control, $P<0.05$ vs. $10 \mu \mathrm{M}$ Marimastat, \#\# $P<0.01$ vs. $10 \mu \mathrm{M}$ Marimastat. 
transforming growth factor- $\alpha$, amphiregulin, tumor necrosis factor- $\alpha$, interleukin- $1 \alpha$, interleukin-1 $\beta$, interferon- $\alpha$, interferon- $\gamma$, and transforming growth factor- $\beta$, as well as by phorbol ester stimulation $^{36)}$. However, poorly differentiated OSCCs, especially SCC-4 cells, may constitutively express MMP-9 mRNA. MMP-9 is closely linked to the metastatic potential of tumors, and enhanced production of MMP-9 has been observed in highly metastatic versus minimally metastatic cell lines ${ }^{37)}$.

Integrins consist of two transmembrane subunits, $\alpha$ and $\beta$, that form a non-covalent heterodimer. Both subunits contribute to the formation of the ligand binding pocket, but the $\alpha$ subunit is likely to play an important role in determining the binding selectivity because heterodimers sharing a common $\beta$ subunit, but with distinct $\alpha$ chains, often bind different ligands ${ }^{38)}$. The binding affinity state of many integrins can be regulated at the cell surface by several stimuli, allowing regulation of the intensity of adhesion during cellular interactions and migration ${ }^{39)}$. Several reports have shown that integrin $\alpha 1 \beta 1$ in particular is associated with migration and invasion of cancer cells ${ }^{40,41)}$. In this study, SCC-4 cells in which integrin $\alpha 1$ mRNA was strongly expressed showed high migration and invasion abilities.

In summary, we used the recently developed RTCA technology to further investigate the migratory and invasion responses associated with MMP-9 in poorly differentiated OSCCs in real time. By this strategy, we demonstrated that SCC-4 cells have high migration and invasion abilities, SAS cells have intermediate abilities, and HO-1-u-1 cells have low, but similar abilities in migration and invasion. Therefore, RTCA will be useful for analyzing the metastatic capability of OSCCs, potentially leading to the development of more effective new drugs for OSCC.

\section{Conflict of interest}

The authors have declared no conflict of interest.

\section{References}

1) Bagan J, Sarrion G, Jimenez Y. Oral cancer: clinical features. Oral Oncol. 2010;46:414-417.

2) Fan S, Tang QL, Lin YJ, et al. A review of clinical and histological parameters associated with contralateral neck metastases in oral squamous cell carcinoma. Int J Oral Sci. 2011;3:180-191.

3) Chambers AF, Groom AC, MacDonald IC. Dissemination and growth of cancer cells in metastatic sites. Nat Rev Cancer. 2002;2:563-572.

4) Grimm M. Prognostic value of clinicopathological parameters and outcome in 484 patients with oral squamous cell carcinoma: microvascular invasion $(\mathrm{V}+)$ is an independent prognostic factor for OSCC. Clin Transl Oncol. 2012; 14:870-880.

5) Nagase H, Woessner JF. Matrix metalloproteinases. J Biol Chem. 1999;274:21491-21494.

6) Uemura S, Matsushita H, Li W, et al. Diabetes mellitus enhances vascular matrix metalloproteinase activity. Circ Res. 2001;88:1291-1298.

7) Visse R, Nagase H. Matrix metalloproteinases and tissue inhibitors of metalloproteinases: structure, function, and biochemistry. Circ Res. 2003;92:827-839.

8) Friedl P, Wolf K. Tube travel: the role of proteases in individual and collective cancer cell invasion. Cancer Res. 2008;68:7247-7249. 
9) Kawamata H, Nakashiro K, Uchida D, et al. Possible contribution of active MMP2 to lymph node metastasis and secreted cathepsin $\mathrm{L}$ to bone invasion of newly established human oral squamous cancer cell lines. Int J Cancer. 1997;70:120-127.

10) Ruokolainen H, Paakko P, Turpeenniemi-Hujanen T. Serum matrix metalloproteinase- 9 in head and neck squamous cell carcinoma is a prognostic marker. Int J Cancer. 2005;116:422-427.

11) Komatsu K, Nakanishi $\mathrm{Y}$, Nemoto N, et al. Expression and quantitative analysis of matrix metalloproteinase-2 and -9 in human gliomas. Brain Tumor Pathol. 2004;21:105-112.

12) Chambers AF, Matrisian LM. Changing views of the role of matrix metalloproteinases in metastasis. $J$ Natl Cancer Inst. 1997;89:1260-1270.

13) $\mathrm{Yu} \mathrm{T}, \mathrm{Wu} \mathrm{Y}$, Helman JI, et al. CXCR4 promotes oral squamous cell carcinoma migration and invasion through inducing expression of MMP-9 and MMP-13 via the ERK signaling pathway. Mol Cancer Res. 2011;9:161-172.

14) Daley WP, Peters SB, Larsen M. Extracellular matrix dynamics in development and regenerative medicine. $J$ Cell Sci. 2008;121:255-264.

15) Page-McCaw A, Ewald AJ, Werb Z. Matrix metalloproteinases and the regulation of tissue remodelling. Nat Rev Mol Cell Biol. 2007;8:221-233.

16) Polacheck WJ, Zervantonakis IK, Kamm RD. Tumor cell migration in complex microenvironments. Cell Mol Life Sci. 2012;70:1335-1356.

17) Ke $\mathrm{N}$, Wang $\mathrm{X}, \mathrm{Xu} \mathrm{X}$, et al. The xCELLigence system for real-time and label-free monitoring of cell viability. Methods Mol Biol. 2011;740:33-43.

18) Atienza JM, Yu N, Kirstein SL, et al. Dynamic and label-free cell-based assays using the real-time cell electronic sensing system. Assay Drug Dev Technol. 2006;4:597-607.

19) Rheinwald JG, Beckett MA. Tumorigenic keratinocyte lines requiring anchorage and fibroblast support cultures from human squamous cell carcinomas. Cancer Res. 1981;41:1657-1663.

20) Kitamura R, Toyoshima $\mathrm{T}$, Tanaka H, et al. Association of cytokeratin 17 expression with differentiation in oral squamous cell carcinoma. J Cancer Res Clin Oncol. 2012;138:1299-1310.

21) Hayashi K, Yokozaki H, Naka K, et al. Effect of 9-cis-retinoic acid on oral squamous cell carcinoma cell lines. Cancer Lett. 2000;151:199-208.

22) Limame R, Wouters A, Pauwels B, et al. Comparative analysis of dynamic cell viability, migration and invasion assessments by novel real-time technology and classic endpoint assays. PLoS One (Internet). 2012;7:e46536. (accessed 2012 Oct 19) Available from: http://www.plosone.org/article/info\%3Adoi\%2F10.1371\%2Fjournal. pone.0046536

23) Tsuchiya H, Iwai S, Kumai T, et al. Increase in matrix metalloproteinase-2 and 9 in the liver of nonalcoholic steatohepatitis model rats. Showa Univ J Med Sci. 2011;23:37-50.

24) Lombard MA, Wallace TL, Kubicek MF, et al. Synthetic matrix metalloproteinase inhibitors and tissue inhibitor of metalloproteinase (TIMP) -2, but not TIMP-1, inhibit shedding of tumor necrosis factor-alpha receptors in a human colon adenocarcinoma (Colo 205) cell line. Cancer Res. 1998;58:4001-4007.

25) Kim HJ, Hawke N, Baldwin AS. NF-kappaB and IKK as therapeutic targets in cancer. Cell Death Differ. 2006;13: 738-747.

26) Xu W, Liu LZ, Loizidou M, et al. The role of nitric oxide in cancer. Cell Res. 2002;12:311-320.

27) Giannelli G, Falk-Marzillier J, Schiraldi O, et al. Induction of cell migration by matrix metalloprotease-2 cleavage of laminin-5. Science. 1997;277:225-228.

28) Lee KS, Jin SM, Kim HJ, et al. Matrix metalloproteinase inhibitor regulates inflammatory cell migration by reducing ICAM-1 and VCAM-1 expression in a murine model of toluene diisocyanate-induced asthma. J Allergy Clin Immunol. 2003;111:1278-1284.

29) Zeng ZS, Cohen AM, Guillem JG. Loss of basement membrane type IV collagen is associated with increased 
expression of metalloproteinases 2 and 9 (MMP-2 and MMP-9) during human colorectal tumorigenesis. Carcinogenesis. 1999;20:749-755.

30) Lu KW, Tsai ML, Chen JC, et al. Gypenosides inhibited invasion and migration of human tongue cancer SCC4 cells through down-regulation of NFkappaB and matrix metalloproteinase-9. Anticancer Res. 2008;28:1093-1099.

31) Rasmussen HS, McCann PP. Matrix metalloproteinase inhibition as a novel anticancer strategy: a review with special focus on batimastat and marimastat. Pharmacol Ther. 1997;75:69-75.

32) Peterson M, Porter KE, Loftus IM, et al. Marimastat inhibits neointimal thickening in a model of human arterial intimal hyperplasia. Eur J Vasc Endovasc Surg. 2000;19:461-467.

33) Skipper JB, McNally LR, Rosenthal EL, et al. In vivo efficacy of marimastat and chemoradiation in head and neck cancer xenografts. ORL J Otorhinolaryngol Relat Spec. 2009;71:1-5.

34) Sparano JA, Bernardo P, Stephenson P, et al. Randomized phase III trial of marimastat versus placebo in patients with metastatic breast cancer who have responding or stable disease after first-line chemotherapy: Eastern Cooperative Oncology Group trial E2196. J Clin Oncol. 2004;22:4683-4690.

35) Kobayashi S, Iwai S, Tsujiyama K, et al. Theaflavin-3,3'-digallate inhibits tube formation in cocultured endothelial cells with fibroblasts. Showa Univ J Med Sci. 2007;19:59-72.

36) Van den Steen PE, Dubois B, Nelissen I, et al. Biochemistry and molecular biology of gelatinase B or matrix metalloproteinase-9 (MMP-9). Crit Rev Biochem Mol Biol. 2002;37:375-536.

37) Okada Y, Gonoji Y, Naka K, et al. Matrix metalloproteinase 9 (92-kDa gelatinase/type IV collagenase) from HT 1080 human fibrosarcoma cells. Purification and activation of the precursor and enzymic properties. J Biol Chem. 1992;267:21712-21719.

38) Tarone G, Hirsch E, Brancaccio M, et al. Integrin function and regulation in development. Int J Dev Biol. 2000; 44:725-731.

39) Hynes RO. Integrins: versatility, modulation and signaling in cell adhesion. Cell. 1992;69:11-25.

40) Yang C, Zeisberg M, Lively JC, et al. Integrin alpha1beta1 and alpha2beta1 are the key regulators of hepatocarcinoma cell invasion across the fibrotic matrix microenvironment. Cancer Res. 2003;63:8312-8317.

41) Aikio M, Alahuhta I, Nurmenniemi S, et al. Arresten, a collagen-derived angiogenesis inhibitor, suppresses invasion of squamous cell carcinoma. PLoS One (Internet). 2012;7:e51044. (accessed 2012 Dec 5) Available from: http:// www.plosone.org/article/info\%3Adoi\%2F10.1371\%2Fjournal.pone.0051044

[Received February 16, 2013 : Accepted February 22, 2013] 